\title{
Pemberdayaan Masyarakat Desa Taman Ayu Melalui Inovasi Teknologi Sistem Integrasi Jagung Dan Sapi (Sijasa)
}

\author{
Mashur1*, Dina Oktaviana $^{2}$, Subagio³, Gargazi Hamid4 \\ 182Fakultas Kedokteran Hewan, UNDIKMA, J1. Pemuda No.59A Mataram, \\ ${ }^{3}$ Prodi Kesmas dan Pendidikan Olah Raga dan Kesehatan, FIKKM, \\ UNDIKMA, J1. Pemuda No.59A, Mataram, Indonesia \\ ${ }^{4}$ Fakultas Teknik Sains dan Terapan, UNDIKMA. J1. Pemuda No.59A, \\ Mataram, Indonesia 83125 \\ Email korespondensi: mashurntb40@gamil.com
}

Diterima: Maret 2021; Revisi: April 2021; Diterbitkan: Juni 2021

\begin{abstract}
The purpose of this PkM activity is to increase the income and welfare of the community, especially beef cattle breeders and to expand employment opportunities in rural areas that are adapted to the agro-ecosystem potential of the village area, namely the corn crop integration system with beef cattle (SIJASA). The method of implementing PKM is the diffusion of science and technology with stages 1) planning, 2) implementation, 3) mentoring and 4) evaluation. Community empowerment activities through the application of SIJASA technology can provide optimal results if the application of the technology degree dissemination method is escorted and accompanied by researchers/lecturers from universities and agricultural extension workers in the field on an ongoing basis under the coordination of related agencies/agencies.
\end{abstract}

Keywords: Innovation, Technology, Maize Beef Integration

\begin{abstract}
Abstrak
Tujuan kegitan PkM ini untuk meningkatkan pendapatan dan kesejahteraan masyarakat khususnya peternak sapi potong serta memperluas lapangan kerja di pedesaan yang disesuaikan dengan potensi agroekosistem wilayah desa, yaitu sistem integrasi tanaman jagung dengan ternak sapi potong (SIJASA). Metode pelaksankaan PKM difusi ilmu pengetahuan dan teknologi dengan tahapan 1) perencaan, 2) Pelaksaan, 3) Pendampingan dan 4) evaluasi. Kegiatan pemberdayaan masyarakat melalui penerapan teknologi SIJASA dapat memberikan hasil yang optimal apabila penerapan metode diseminasi gelar teknologi dikawal dan didampingi oleh peneliti/dosen dari perguruan tinggi dan penyuluh pertanian di lapangan secara berkesinambungan di bawah koordinasi dinas/instansi terkait.
\end{abstract}

Kata Kunci: Inovasi, Teknologi, Integrasi Jagung Sapi

How to Cite: Mashur., Oktaviana D., Subagio, Hamid G. (2021). Pemberdayaan Masyarakat Desa Taman Ayu Melalui Inovasi Teknologi Sistem Integrasi Jagung Dan Sapi (Sijasa). SASAMBO: Jurnal Abdimas (Journal of Community Service). 3(2), 57-69. DOI: $10.36312 /$ sasambo.v3i2.422 


\section{LATAR BELAKANG}

Desa Taman Ayu merupakan salah satu desa dari 11 desa yang berada di wilayah Kecamatan Gerung Kabupaten Lombok Barat Provinsi Nusa Tenggara Barat (NTB). Desa Taman Ayu merupakan desa pemekaran dari Desa Kebon Ayu yang ditetapkan secara definitive berdasarkan Surat Keputusan Bupati Lombok Barat tanggal 17 September 2012 No 1267/127/BPMPD/2012. Secara administratif Desa Taman Ayu memiliki luas wilayah $640 \mathrm{~km}^{2}$ terdiri dari 6 dusun dengan $13 \mathrm{RT}$ yaitu Dusun Bongor, Dusun Karang Genteng, Dusun Peseng, Dusun Gunung Malang, Dusun Taman, dan Dusun Jeranjang. Desa Tanam Ayu merupakan lokasi pembangkit listrik tenaga uap (PLTU) yang mensuplai kebutuhan terbesar listrik di NTB. Batas Desa Taman Ayu di sebelah utara adalah Desa Kuranji, sebelah timur Desa Suka Makmur, sebelah selatan Desa Kebon Ayu dan sebelah barat Selat Lombok. Berdasarkan orbitasi, jarak ke ibu kota kecamatan $9 \mathrm{~km}$ dengan lama tempuh 20 menit. Sedangkan jarak ke ibu kota kabupaten $10 \mathrm{~km}$ dengan lama tempuh ke ibu kota kabupaten sekitar 30 menit. (Pemerintahan Desa Taman Ayu, 2015).

Desa Taman Ayu memiliki wilayah dengan bentuk lahan datar dan sebagian berbukit. Wilayah ini beriklim tropis dengan dua musim, yaitu musim hujan dan musim kemarau. Desa Taman Ayu memiliki potenisi iklim yang sangat sesuai untuk pengembangan pertanian, karena memiliki curah hujan harian rata-rata $200 \mathrm{~mm}$, jumlah bulan hujan 4 bulan dengan curah hujan tahunan mencapai $134,29 \mathrm{~mm}$. Suhu harian rata-rata berkisar $20-25^{\circ} \mathrm{C}$ dan berada pada ketinggian $2,5 \mathrm{~m}$ di atas permukaan laut. Berdasarkan tipologi wilayah, Desa Tanam Ayu termasuk desa yang dapat dikembangkan dalam integrasi sistem usaha pertanian tanaman pangan jagung dengan peternakan sapi potong.(Pemerintahan Desa Taman Ayu, 2015)

Jumlah penduduk Desa Taman Ayu sebanyak 6.465 jiwa atau 2.173 KK terdiri dari laki-laki 3.235 jiwa dan perempuan 3.230 jiwa. Berdasarkan potensi sumberdaya manusia sebagian besar $(61,55 \%)$ atau 3.979 orang penduduknya tergolong usia produktif dengan komposisi usia 21-60 tahun. Mata pencaharian penduduk $80 \%$ rumah tangga merupakan petani peternak dan sisanya sebagai pedagang dan pegawai. Luas lahan di desa Taman Ayu 320,365 ha terdiri dari lahan pertanian/sawah 123 ha, tanah kebun 28 ha, pemukiman penduduk 123 ha dan lain-lain 46 ha. Sebagian besar lahan pertanian merupakan lahan kering atau tadah hujan (Pemerintahan Desa Taman Ayu, 2015).

Prioritas utama dalam pemberdayaan masyarakat akan diarahkan pada pengembangan potensi sumberdaya alam berbasis pertanian dan peternakan. Hal ini didasarkan pada jumlah penduduk di Desa Taman Ayu 80\% rumah tangga merupakan petani (Pemerintahan Desa Taman Ayu, 2015). Model yang akan dikembangkan dalam rangka meningkatkan pendapatan dan kesejahteraan masyarakat serta memperluas lapangan kerja di pedesaan akan disesuaikan dengan potensi agroekosistem wilayah desa, yaitu sistem integrasi tanaman jagung dengan ternak sapi potong dengan akronim "SIJASA". Inovasi SIJASA dapat memanfaatkan limbah tanaman jagung sebagai pakan sapi dan sebaliknya limbah kotoran sapi diolah menjadi pupuk organik tanaman jagung. Inovasi SIJASA akan meningkatkan efisiensi biaya produksi usahatani tanaman jagung dan ternak sapi, sehingga pendapatan dan kesejahteraan petani dapat 
meningkat. Tahap awal yang akan dilakukan adalah penguatan kelembagaan kelompok petani peternak, dengan cara pembentukan kelompok kandang ternak kolektif (kandang kumpul). Kelompok tani ternak ini selanjutnya secara bertahap akan didampingi, dikawal dan difasilitasi dengan berbagai inovasi teknologi melalui berbagai kegiataan pemberdayaan sehingga akan terbentuk Gabungan Kelompoktani (Gapoktan) di desa. Gapoktan selanjutnya akan difasilitasi agar menjadi kelembagaan ekonomi petani dalam bentuk Koperasi Petani Peternak Sapi Potong). Dengan demikian, secara bertahap Desa Taman Ayu akan menjadi embrio terbentuknya Desa Sentra Produksi Sapi Potong di Kabupaten Lombok Barat.

Selama ini pengembangan usaha budidaya jagung dilakukan para petani secara parsial dengan usaha pemeliharaan sapi potong, sehingga belum memberikan keuntungan yang optimal bagi petani. Pengembangan inovasi sistem integrasi sapi dan jagung selain dapat meningkatkan pendapatan petani peternak juga dapat mengurangi biaya produksi untuk budidaya tanaman jagung dan mengurangi biaya pakan ternak sapi potong. Pemanfaatan kotoran ternak menjadi pupuk organik padat dan kencing sapi menjadi pupuk organik cair dapat mengurangi penggunaan pupuk kimia, sehingga dapat mengurangi biaya untuk pemupukan tanaman jagung. Di samping itu, penggunaan limbah jagung sebagai baku utama pembuatan pakan sapi potong dapat mengurangi biaya pakan dari usaha pemeliharaan sapi potong. Introduksi teknologi pembuatan pakan sapi potong dalam bentuk silase, jerami fermentasi dan pelet memiliki keunggulan dalam pemanfaatan limbah jagung sebagai pakan ternak. Hal ini diharapkan sebagai solusi untuk beternak sapi potong tanpa rumput secara komersial dengan skala usaha 5-10 ekor/KK. Keunggulan lain dari teknologi pembuatan pakan sapi potong dari limbah jagung adalah dapat disimpan cukup lama hingga waktu satu tahun apabila kadar airnya mencapai $12-15 \%$. Dengan demikian, dapat dijadikan sebagai solusi untuk mengatasi kesulitan penyediaan pakan ternak pada musim kemarau, di mana para peternak sering mengalami kesulitan penyediaan pakan.

Berdasarkan Profil Desa Taman Ayu Tahun 2015 (Pemerintahan Desa Taman Ayu, 2015) terdapat berbagai masalah atau tantangan dalam bidang ekonomi yang dihadapi antara lain pendapatan masyarakat rendah karena jenis usaha terbatas, kelompok-kelompok yang dibentuk (SPP, BUMDES, koperasi) banyak yang macet, daya beli masyarakat kurang, bibit pertanian terbatas serta kurangnya bibit unggul, petani peternak bukan milik sendiri melainkan pengkadas, tidak memiliki pasar, lembaga keuangan terbatas, warga kebayakan buruh tani/pekerja, angka pengangguran tinggi, lahan terbatas, banyak tengkulak, irigasi kekurangan air, home industri sulit mengembangkan produksi, pengusaha kecil kekurangan modal, alat pengelolaan lahan terbatas menyebabkan hasilnya rendah, produksi pertanian masyarakat kurang optimal, pengangkutan hasil pertanian sulit karena jalan desa rusak dan alat angkutan terbatas, modal untuk pengolahan lahan kurang, tidak tersedia tempat khusus untuk pakan ternak, masyarakat tidak memiliki keahlian tentang penyakit ternak, warga tidak punya ke ahlian untuk mengelola lahan dan mengetahui jenis penyakit yang menyerang tanaman, petani kekurangan air untuk mengairi lahan sawah. Masalah sosial budaya yang menjadi masalah atau tantangan mencakup pengangguran tinggi, alat transportasi terbatas, masih sulitnya 
mengumpulkan masyarakat ketika melakukan pertemuan di kantor desa, masih terbatasnya lampu penerangan (listrik), belum maksimalnya Pemerintah Desa dalam membina dan memberdayakan kelompok pemakai air, ketika musim kemarau kesulitan untuk air bersih/konsumsi rumah tangga, tidak ada sarana mengaji untuk anak-anak, banyak warga menikah di usia muda/dibawah umur, pendapatan RT rendah, kelembagaan desa belum berperan aktif, belum adanya komonikasi aktif antar lembagalembaga desa, sarana olah raga yang terbatas, kesenian tradisional tidak berkembang/dilestarikan, lemahnya kapasitas Aparatur Desa dalam pengadministrasian penyusunan data-data dan sarana pendukung lain (terutama dalam pengelolaan ADD), pendokumentasian, beberapa lembaga desa kurang aktif dan kapasitasnya kurang.

Dari analisis data dan informasi tersebut telah diidentifikasi sumbersumber penghidupan utama masyarakat Desa Taman Ayu yaitu dari sektor pertanian, peternakan, perkebunan dan perikanan. Penentuan arah kebijakan pembangunan Desa Taman Ayu sampai tahun 2021 yang tertuang dalam Rencana Kerja Pembangunan Desa (RKP-Des) setiap tahun yang berorientasi pada peningkatan kualitas sumber daya manusia di segala bidang sehingga mampu mengelola sumber daya alam yang lestari dengan titik berat pembangunan pada sektor pertanian dan peternakan.

Tujuan umum pemasyarakatan Inovasi Sistem Integrasi Jagung dan Sapi (SIJASA) selain untuk meningkatkan pendapatan masyarakat di kawasan PLTU Jeranjang melalui introduksi berbagai komponen teknologi budidaya jagung dan sapi, penguatan kelembagaan, peningkatan kapasitas SDM dan pendampingan masyarakat untuk mewujudkan Desa Taman Ayu sebagai Desa Sentra Produksi Sapi Potong di Nusa Tenggara Barat adalah: (1) untuk memasyakatkan hasil riset unggulan Undikma dalam membangun masyarakat Desa Taman Ayu, (2) membantu program pemerintah di Kabupaten Lombok Barat dalam pembangunan masyarakat dan wilayah desa; (3) membantu mensukseskan terlaksananya program Rencana Pembangunan Jangka Menengah Desa Taman Ayu dalam bidang ekonomi; (4) meningkatkan kemandirian dan kesejahteraan masyarakat Desa Taman Ayu; 5) mempercepat pembangunan Desa Taman Ayu pada berbagai bidang secara berkelanjutan; dan (6) memperkuat sinergisme Undikma dengan Pemda Kabupaten Lombok Barat terkait dalam pembangunan Desa Taman Ayu.

Tujuan khusus Pemasyarakatan Inovasi Sistem Integrasi Jagung dan Sapi (SIJASA) di kawasan PLTU Jeranjang Desa Taman Ayu adalah: (1) memberikan solusi permasalahan masyarakat Desa Taman Ayu dalam meningkatkan pendapatan dan kesejahteraan dan pengurangi pengangguran di pedesaan dengan pendekatan holistic berbasis riset multidisiplin; (2) mengaplikasikan hasil riset unggulan Undikma yang sesuai dengan urgensi kebutuhan masyarakat Desa Taman Ayu; (3) memberikan penguatan potensi masyarakat Desa Taman Ayu melalui aplikasi hasil riset unggulan Undikma (sistering desa) berupa inovasi SIJASA dan teknologi pembuatan pakan sapi potong berbasis limbah jagung; dan (4) membentuk Desa Mitra Taman Ayu sebagai salah satu model science-techno-park Undikma dan (5) menjadikan Desa Taman Ayu sebagai Desa Sentra Produksi Sapi Potong untuk memenuhi kebutuhan sapi potong di NTB. 


\section{METODE PELAKSANAAN}

Adapun Program Kemitraan pada Masyarakat (PKM) dilaksanakan dengan metode difusi ilmu pengetahuan dan teknologi. Kegitan ini dilaksanakan di Desa Taman Ayu sebagai salah satu sentra produksi sapi potong di Nusa Tenggara Barat. Tahapan-tahapan kegitan sebagai beriku;

1. Melakukan focus group discussion (FGD) dengan tokoh masyarakat, tokoh agama, aparat pemerintahan desa (kepala dusun), dan anggota kelompok tani yang berada di wilayah sekitar PLTU Jeranjang. Berdasarkan hasil diskusi ini dapat diidentifikasi masalah-masalah prioritas yang akan dicarikan alternative pemecahannya secara partisipatif.

2. Berdasarkan prioritas masalah yang dihadapi dan diharapkan dapat diselesaikan dengan segera maka dilakukan berbagai kegiatan pemberdayaan petani melalui berbagai kegiatan penyuluhan sesuai dengan kebutuhan petani (Mashur et al., 2020a)

3. Setelah dilakukan berbagai kegiatan penyuluhan selanjutnya dilakukan penerapan teknologi sistem integrasi sistem budidaya jagung dan pemeliharaan sapi potong dengan metode gelar teknologi (Mashur et al., 2020b)

4. Pelaksanaan gelar teknologi dilakukan melalui penetapan petani kooperator (petani pelaksana), yang ditetapkan berdasarkan kriteria tertentu, misalnya petani bersifat inovatif, kreatif dan memiliki fasilitas (sarana prasarana) untuk pelaksanaan gelar teknologi serta disepakati oleh anggota kelompoktani.

5. Agar kegiatan pemberdayaan masyarakat khususnya petani peternak dapat berjalan secara berkesinambungan maka dilakukan pendampingan teknologi yang diintroduksi oleh peneliti/dosen dari Fakultas Kedokteran Hewan Universitas Pendidikan Mandalika dan penyuluh pertanian lapangan (PPL) yang bertugas di Desa Taman Ayu

6. Untuk menjamin dan memastikan semua kegiatan dapat berjalan sesuai dengan rencana pemberdayaan maka dilakukan monitoring dan evaluasi secara berkala (awal kegiatan, saat kegiatan berlangsung dan akhir kegiatan)

Kegiatan pemberdayaan masyarakat dalam penerapan teknologi sistem integrasi jagung dan sapi (SIJASA) dilakukan selama enam bulan (JanuariJuni 2019) di Dusun Jeranjang Desa Taman Ayu Kecamatan Gerung Kabupaten Lombok Barat. Kegiatan dilaksanakan atas kerjasama Universitas Nusa Tenggara Barat (UNTB/UNDIKMA) dengan Kantor Desa Taman Ayu.

\section{HASIL DAN PEMBAHASAN}

Berdasarkan hasil Fokus Group Diskusi (FGD) tokoh masyarakat, tokoh agama, aparat pemerintahan desa (kepala dusun), dan anggota kelompok tani yang berada di wilayah sekitar PLTU Jeranjang dapat diidentifikasi masalah-masalah yang dihadapi yang akan digunakan sebagai dasar untuk menetapkan inovasi yang akan diterapkan. Ada 19 masalah yang telah diidentifikasi, yaitu: (1) Terbatasnya sarana produksi dan modal usaha, (2) Terbatasnya kemampuan petani untuk mengolah hasil yang memberikan nilai tambah, (3) Hasil produksi pertanian tidak maksimal, (4) Terbatasnya sarana pengolahan hasil produksi dan harga di tentukan oleh pengusaha, (5) Produksi hasil laut kurang, (6) Sering terjadi wabah penyakit 
malaria dan muntaber, (7) Harga kebutuhan pokok naik, (8) Terbatasnya penyediaan air bersih pada musim kemarau, (9) Masyarakat sering mengalami kekurangan modal untuk menggarap ladang, (10) Masih adanya angka pengangguran dan masyarakat penyandang penyakit kesejahteraan sosial, (11) Masih adanya prasarana transportasi yang kurang memadai, (12) Saluran irigasi tidak layak, (13) Masih ada balita BGM/gizi buruk, (14) Masih ada masyarakat miskin dan tinggal dirumah tidak layak huni (kumuh), (15) Masih ada angka buta aksara dan masih adanya drop/out, (16) Konflik antar keluarga/warga, (17) Konflik antar petani pemakai air sering terjadi, (18) Pengambilan (eksploitasi) bahan galian C cenderung merusak lingkungan, (19) Sarana dan prasarana pelayanan publik masih belum memadai dan fasilitas kantor desa belum lengkap.

Berdasarkan masalah-masalah yang telah diidentifikasi tersebut telah ditetapkan jenis-jenis inovasi teknologi dalam sistem integerasi jagung dan sapi potong dengan rekayasa sosial dan ekonomi penguatan kapasitas kelembagaan kandang kolektif berbasis budaya local, sesuai hasil penelitian Mashur et al. (2020c), terdiri dari:

(1) Revitalisasi atau pembentukan pengurus kelompok kandang kolektif pada setiap dusun

(1) Penetapan lokasi dan desain kandang kolektif (bagi yang belum memiliki)

(2) Penataan (pembuatan) kandang kolektif yang sehat

(3) Penyusunan awiq-awiq kelompok kandang kolektif

(4) Penguatan administrasi kelompok

(5) Penyusunan program kerja kelompok

(6) Inisiasi pembentukan kelembagaan ekonomi (koperasi) gabungan kelompoktani (gapoktan)

Adapun kegiatan-kegiatan yang telah dilakukan dalam rangka pemberdayaan masyarakat khususnya petani jagung dan peternak sapi potong di Dusun Jeranjang Desa Taman Ayu sebagai berikut:

(1) Pertemuan pembentukan pengurus kelompok kandang kolektif pada masing-masing dusun

(2) Pertemuan penetapan lokasi dan desain kandang kolektif (bagi yang belum memiliki)

(3) Pertemuan penataan (pembuatan) kandang kolektif yang sehat (Mashur, 2015)

(4) Pertemuan penyusunan awiq-awiq kelompok kandang kolektif (Mashur et al., 2015)

(5) Pertemuan penguatan administrasi kelompok

(6) Pertemuan penyusunan program kerja kelompok

(7) Pertemuan inisiasi pembentukan kelembagaan ekonomi (koperasi) gabungan kelompoktani (gapoktan)

Kegiatan-kegiatan pemberdayaan masyarakat petani tersebut adalah proses perubahan perilaku, pola pikir dan sikap petani dari cara tradisional menjadi cara-cara modern yang berwawasan agribisnis melalui proses pembelajaran. Hal ini sesuai dengan pernyataan Warsana (2020).

Inovasi teknologi yang telah diintroduksi dalam rangka pemberdayaan masyarakat khususnya petani peternak sapi potong di Dusun Jeranjang Desa Taman Ayu Kecamatan Gerung Kabupaten Lombok Barat, adalah:

(1) Pembuatan kompos dari kotoran sapi dan limbah pakan, terdiri dari berbagai kegiatan antara lain: 
a. Pembuatan gudang pengolahan kompos

b. Pertemuan pembuatan gudang pengolahan kompos

c. Pembuatan gudang pengolahan kompos

d. Pelatihan Pembuatan mikroorganisme lokal (MOL)

e. Pelatihan Penggunaan MOL untuk pembuatan kompos

f. Pelatihan Pengemasan dan pemasaran kompos

g. Demplot penggunaan kompos sebagai pupuk tanaman jagung, dll

h. Temu lapang

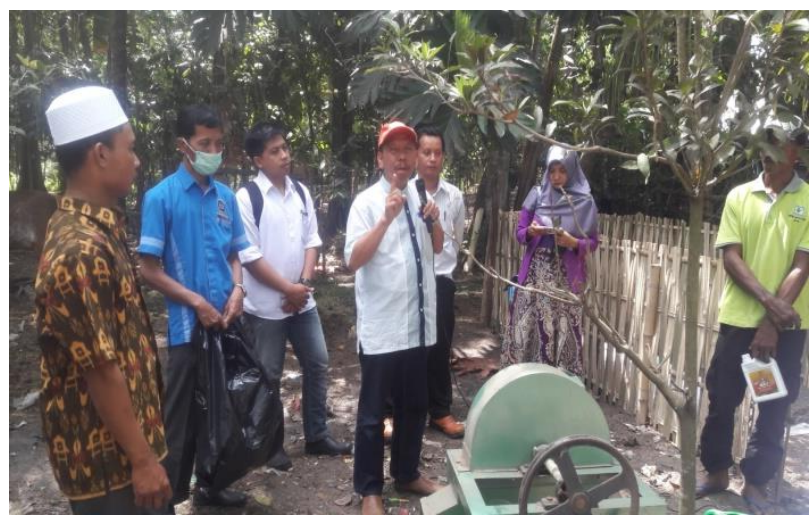

Gambar 1. Kegiatan penyuluhan pembuatan kompos, bio urin, MOL dan silase dari limbah jagung oleh tim peneliti dari UNTB/Undikma.

(2) Pembuatan biourin dari air kencing sapi

a. Pelatihan Pembuatan instalasi produksi bio urin

b. Pelatihan Pembuatan mikroorganisme lokal (MOL)

c. Pelatihan Penggunaan MOL untuk pembuatan bio urin

d. Pelatihan Pengemasan dan pemasaran bio urin

e. Demplot penggunaan bio urin sebagai organik cair tanaman jagung, dll

f. Temu lapang

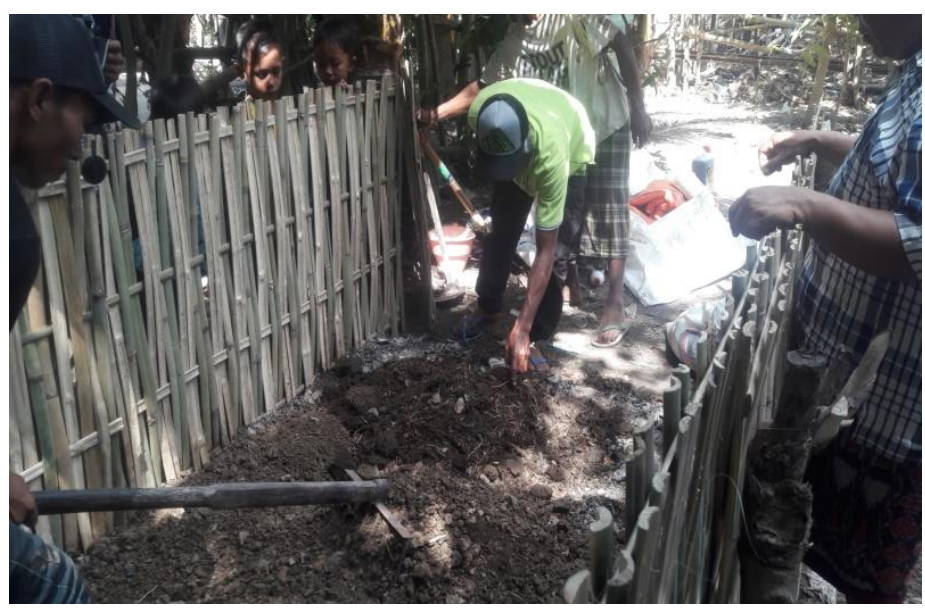

Gambar 2. Gelar teknologi pembuatan kompos dari kotoran sapi dan sisa pakan di kandang yang didampingi oleh tin peneliti dari UNTB/Undikma 


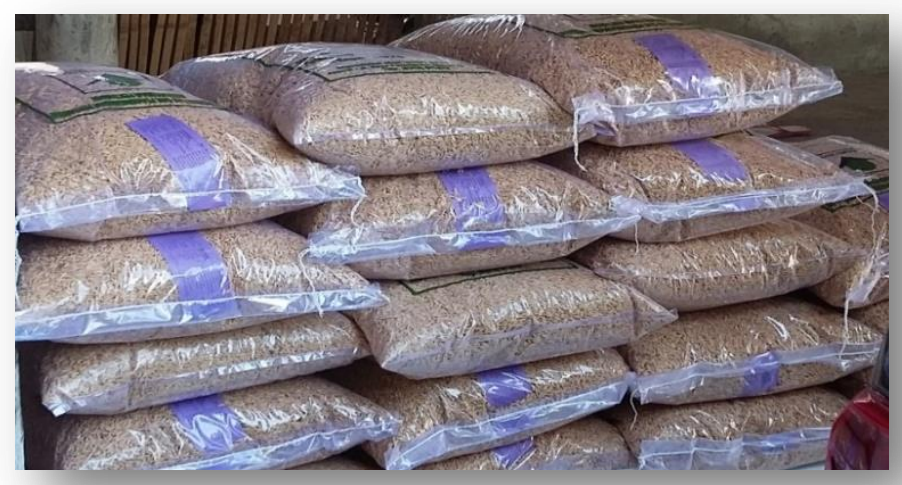

Gambar 3. Produksi kompos yang sudah dihasilkan petani dan dikemas untuk dijual

(3) Pembuatan silase atau fermentasi limbah jagung sebagai pakan sapi

a. Pembuatan gudang prosesing dan penyimpanan pakan olahan

b. Pembuatan pakan olahan berbasis limbah jagung

c. Demplot pemberian pakan olahan pada penggemukan ternak sapi

d. Pengemasan dan pemasaran pakan olahan

e. Temu lapang

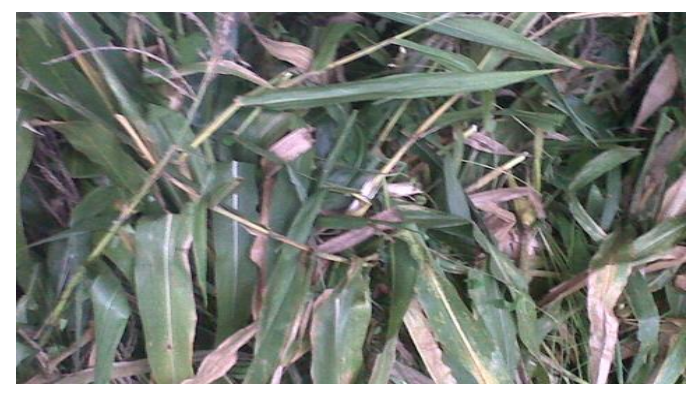

Gambar 4. Limbah jagung yang akan dimanfaatkan untuk membuat silase pakan sapi potong

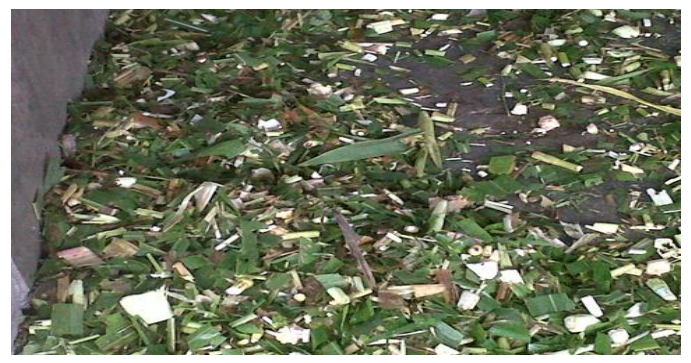

Gambar 5. Limbah jagung yang sudah dipotong halus dan siap digunkan sebagai bahan untuk membuat silase pakan sapi potong

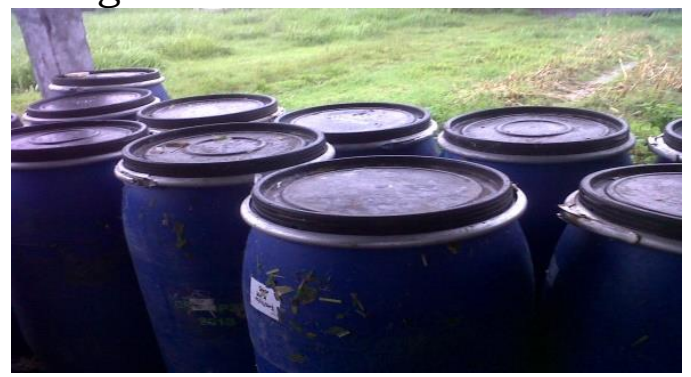

Gambar 7. Limbah jagung yang sedang difermentasi untuk mendapatkan silase yang berkualitas 
(4) Pelaksanaan IB mendukung program OPSUS SIWAB (sapi induk wajib bunting) dengan menerapkan kalender kawin:
a. Indentifikasi dan pendataan induk sapi
b. Pemeliharaan kesehatan ternak (vaksinasi, pemberian obat cacing dan vitamin)
c. Pelatihan IB dan penerapan kalender kawin
d. Pelaksanaan demplot IB dan kalender kawin
e. Temu lapang

(5) Pelaksanaan demplot penanaman jagung panen muda (jamu)

a. Aplikasi penggunaan kompos dan biourin

b. Aplikasi tanam jagung panen muda

c. Temu lapang

Pembuatan kompos menggunakan dekomposer Stardek kompos yang dihasilkan sebagian digunakan untuk pupuk organik berbagai jenis tanaman seperti padi, kacang tanah, cabe, terung dan tanaman hijauan pakan ternak. Sebagian kompos yang diproduksi dijual dengan harga Rp 900,-/kilogram. Hasil percobaan menggunakan kompos pada tanaman padi menunjukkan berkurangnya gulma dibandingkan dengan yang tanpa menggunakan kompos Mashur (2015).

Kegiatan-kegiatan pemberdayaan yang dilakukan terhadap masyarakat di Dusun Jeranjang tersebut berbasis inovasi teknologi sistem integrasi tanaman jagung dan sapi potong telah sesuai dengan pendapat Suprapto (2009) bahwa pemberdayaan masyarakat tani melalui teknologi dan informasi pertanian secara ekslusif bertujuan untuk mengoptimalkan potensi sumberdaya pertanian yang tersedia. Pendekatannya dapat ditempuh melalui inisiasi pembentukan Farmer Managed Activity (FMA) yang kegiatannya meliputi pemberdayaan petani dan kelembagaanya.

Pemasyarakatan Inovasi Sistem Integrasi Jagung dan Sapi (SIJASA) untuk meningkatkan pendapatan masyarakat di kawasan PLTU Jeranjang melalui introduksi beberapa komponen teknologi juga diharapkan untuk mewujudkan Desa Taman Ayu sebagai sentra produksi sapi potong di Nusa Tenggara Barat. Penerapan integrasi dilakukan untuk meningkatkan efesiensi dan nilai tambah sumberdaya. Integrasi tanaman-ternak dapat meningkatkan kontribusi terhadap pendapatan petani mencapai 43,95\% (Hermawan, 1994). Pengelolaan usaha ternak sapi diharapkan dapat meningkatkan bahan organik tanah yang nantinya dapat mengurangi ketergantungan penggunaan pupuk anorganik karena adanya substitusi bahan organik yang dihasilkan dari ternak, sehingga tercipta agroekosistem low externalinput sustainable agriculture/LEISA (Dwiyanto, 2000).

Menurut Kariyasa (2005) model integrasi tanaman-ternak dapat mengatasi masalah ketersediaan pakan. Ternak dapat memanfaatkan limbah tanaman seperti jerami padi, jerami jagung, limbah kacangkacangan, dan limbah pertanian lainnya, terutama pada musim kemarau (Mashur, 2017). Limbah pertanian dapat menyediakan pakan 33,30\% dari total rumput yang dibutuhkan. Pemanfaatan limbah pertanian, selain mampu meningkatkan "ketahanan pakan" terutama pada musim kemarau, juga dapat menghemat tenaga kerja untuk menyediakan pakan (rumput), sehingga memberi peluang bagi petani untuk meningkatkan jumlah ternak 
yang dipelihara (Mashur et al., 2015). Selanjutnya Kariyasa (2005) menyatakan, usaha ternak yang dikelola secara terpadu dengan usaha tani padi, yakni dengan memanfaatkan jerami padi sebagai pakan, hanya membutuhkan biaya tenaga kerja Rp. 410.000-589.000/ekor. Usaha ternak sapi yang dikelola secara parsial (tidak menggunakan jerami padi) membutuhkan biaya tenaga kerja Rp.735.000-1.377.000/ekor. Dengan demikian, usaha ternak dengan memanfaatkan limbah pertanian mampu menghemat biaya tenaga kerja 35,44-44,22\% atau 5,26-6,38\% terhadap total biaya usaha ternak. Menurut Mashur et al. (2015) bahwa usaha ternak sapi potong yang dilaksanakan secara terintegrasi dengan padi memberikan keuntungan paling tinggi, yakni 84\%, sementara pada usaha tani padisayuran-ternak, pendapatan hanya meningkat $10 \%$, padi-ternakikan $2 \%$, padi-sayuran-ternak-ikan $2 \%$, dan sayuran-ternak (2\%). Ternak sapi memberikan kontribusi terhadap pendapatan sebesar Rp3.188.725, dan pendapatan dari usaha nonternak (padi-palawija-sayuranikan) Rp.5.078.414. Menurut Roessali et al. (2005), upaya untuk mendorong partisipasi petani dapat dilakukan melalui usaha ternak yang terintegrasi dengan kegiatan pertanian lainnya yang lebih besar dan layak secara ekonomi, yaitu melalui sistem agribisnis.

Pemasyarakatan Inovasi Sistem Integrasi Jagung dan Sapi (SIJASA) di kawasan PLTU Jeranjang melalui introduksi beberapa komponen teknologi budidaya jagung dan sapi potong dalam suatu sistem yang terintegrasi merupakan kebutuhan yang sangat mendesak dan sejalan dengan program pembangunan desa Taman Ayu untuk mewujudkan Desa Taman Ayu sebagai Desa Sentra Produksi Sapi Potong di Nusa Tenggara Barat dalam rangka meningkatkan pendapatan dan kesejahteraan masyarakat berdasarkan RPJM 2015-2021.

Untuk itu, maka diidentifikasi penanganan akar masalah yang akan diprioritaskan untuk diatasi yaitu revitaliasi keberadaan kelembagaan kelompoktani (poktan) dan gabungan kelompoktani (gapoktan) berbasis kandang kolektif, penataan dan rancang bangun kandang kolektif agar memenuhi persyaratan kesehatan ternak, peningkatan kemampuan (pengetahuan, keterampilan dan sikap) anggota kelompok tani dalam penerapan inovasi teknologi sistem integrasi sapi jagung, pembuatan pupuk oragnik padat (kompos) dan cair (biourine) sapi, pembuatan pelet pakan sapi potong dari limbah jagung dan aplikasi pengunaan kompos pada tanaman jagung, melalui berbagai kegiatan pelatihan, penyuluhan, bimbingan teknis, magang petani peternak dan pendampingan secara berkelanjutan oleh dosen dan mahasiswa UNTB/Undikma dan pihak yang terkait (Mashur, 2017).

Pemilihan komoditas sapi potong dalam penetapan luaran Program Pengembangan Desa Mitra (PPDM) Desa Taman Ayu sebagai Desa Sentra Produksi Sapi potong, karena sapi potong merupakan penyumbang daging terbesar dari kelompok ruminansia terhadap produksi daging nasional sehingga usaha ternak ini berpotensi untuk dikembangkan sebagai usaha yang menguntungkan. Sapi potong telah lama dipelihara oleh sebagian masyarakat di Desa Taman Ayu sebagai tabungan dan tenaga kerja untuk mengolah tanah dengan manajemen pemeliharaan secara tradisional. Pola usaha ternak sapi potong sebagian besar berupa usaha rakyat untuk menghasilkan bibit atau penggemukan, dan pemeliharaan secara 
terintegrasi dengan tanaman pangan maupun tanaman perkebunan (Mashur et al., 2015)

\section{KESIMPULAN}

Kegiatan-kegiatan pemberdayaan yang dilakukan terhadap masyarakat di Dusun Jeranjang Desa Taman Ayu tersebut berbasis inovasi teknologi sistem integrasi tanaman jagung dan sapi potong (SIJASA) adalah pemberdayaan masyarakat tani melalui teknologi dan informasi pertanian secara ekslusif untuk mengoptimalkan potensi sumberdaya pertanian yang tersedia dengan tujuan untuk meningkatkan pendapatan dan kesejahteraan masyarakat khususnya petani peternak sapi potong. Kegiatan-kegiatan pemberdayaan masyarakat petani tersebut adalah proses perubahan perilaku, pola pikir dan sikap petani dari cara tradisional menjadi cara-cara modern yang berwawasan agribisnis melalui proses pembelajaran pembuatan pupuk organik padat (kompos) dari kotoran sapi, pembuatan pupuk organik cair (biourin) dari urin sapi dan pembutan silase pakan sapi potong dari limbah jagung. Penerapan teknologi SIJASA dilakukan melului metode gelar teknologi yang dikawal dan didampingi oleh peneliti/dosen dari Undikma dan penyuluh pertanian di lapangan..

\section{SARAN}

Untuk mewujudkan Desa Taman Ayu sebagai desa sentra produksi jagung dan sapi potong di Nusa Tenggara Barat maka kegiatan pemberdayaan masyarakat melalui inovasi sistem integerasi tanaman jagung dan sapi potong (SIJASA) dapat terus ditingkatkan secara berkesinambungan melalui berbagai kegiatan penyuluhan dan pengawalan serta pendampingan teknologi oleh peneliti/dosen dari perguruan tinggi dan penyuluhan pertanian di lapangan di bawah koordinasi Dinas Pertanian dan Peternakan baik di Kecamatan Gerung, Kabupaten Lombok Barat maupun di Provinsi Nusa Tenggara Barat.

\section{UCAPAN TERIMAKASIH}

Ucapan terima kasih disampaikan kepada Kepala Dusus Jeranjang dan Kepala Desa Taman Ayu Kecamatan Gerung Kabupaten Lombok Barat, kepada Ketua dan anggota Kelompoktani di Dusun Jeranjang serta penyuluh pertanian lapangan (PPL) desa Taman Ayu yang telah memfasilitasi pelaksanaan kegiatan pemberdayaan masyarakat di Dusun Jeranjang sehingga kegiatan ini telah berjalan dengan baik. Ucapan terima kasih juga kami sampikan kepada Rektor UNTB yang telah memberikan dukungan dan fasilitas KKN Tematik di Desa Taman Ayu tahun 2018 yang dipadukan dengan kegiatan pemberdayaan masyarakat, sehingga kegiatan pengabdian kepada masyarakat ini dapat berjalan dengan baik.

\section{DAFTAR PUSTAKA}

Dwiyanto, K. 2000. Restukturisasi Peta Kesesuaian dan Pemberdayaan Sumberdaya Unggulan (Pembangunan Pertanian-Peternakan di Indonesia). Materi Pelatihan: Revitalisasi Keterpaduan Usaha Ternak Dalam Sistem Usahatani. Puslitbangnak, Bogor. https://jurnal.uns.ac.id/Sains-Peternakan/article/view/4924

Hermawan, A. 1994. Implikasi Penguasaan Lahan Terhadap Pengembangan Ternak di Pedesaan Lahan Kering DAS. Prosiding Pertemuan Ilmiah 
Hasil Penelitian Peternakan Lahan Kering. Sub Balai Penelitian Ternak, Grati. https://ojs.unud.ac.id , pastura , article , download

Kariyasa, K. 2005. Sistem Integrasi Tanaman Ternak Dalam Perspektif Reorientasi Kebijakan Subsidi Pupuk Dan Peningkatan Pendapatan Petani. Jurnal Analisis Kebijakan Pertanian 3(1): 68-80. http://ejurnal.litbang.pertanian.go.id/index.php/akp/article/view/683 $\underline{5 / 6075}$

Mashur, Wirapribadi dan Imran. 2015. Pengembangan Model Integrasi Sapi Jagung Dan Rumput Laut (PIJAR) Dalam Rangka Optimalisasi Pendapatan Petani Di NTB. Proposal Penelitian Prioritas Nasional Masterplan Percepatan Dan Perluasan Pembangunan Ekonomi Indonesia 2011- 2025 (PENPRINAS MP3EI 2011-2025)

Mashur. 2015. Manajemen Kandang Kolektif Untuk Menunjang Integrasi Ternak Pada Sawah Irigasi (kasus pada Kelompok Ternak Gerak Maju Desa Sepakek Kecamatan Pringgarata Kabupaten Lombok Tengah. Jurnal Sangkareang Mataram. 1(1): 19-25 https://sinta.ristekbrin.go . id $/$ authors $/$ detail? page $=2 \&$ id $=5988794 \&$ view=documentsgs

Mashur. 2017. The Main Problem of Smallholder Farming in Facing the ASEAN Economic Community in the Producing Region of Beef Cattle in West Nusa Tenggara. The 5th International Seminar Of Animal Nutrition and Feed Sciences "Improving Livestock Productivity, Quality and Safety to Respond to the Increasing Demand from Upper and MiddleClass Consumers"1(1):276-294 https://www.agropustaka.id/ wpcontent/uploads/2020/02/ ainionline.org_Proceedings-The-5thInternational-Seminar-of-Animal-Nutrition-Feed-Sciences-2017-1.pdf

Mashur, D. Oktaviana, Kholik and K. Tirtasari. 2018. Determination of Success Factors Smallholders Livestock in Realizing Beef Self Sufficiency in West Tenggara Barat. The 3rd International Conference on Science and Technology (ICST 2018) "Emerging Sciences and Technology for Human Prosperity and Health". 1(1): 79-100 http://eprints.unram.ac.id/14330/1/Prosiding-ICST_compressed.pdf

Mashur, Hunaepi, Oktaviana D., Kholik, Tirtasari K., \& Jannah M (2020a) Metode Diseminasi Teknologi Hasil Penelitian Peternak Sapi Potong di Nusa Tenggara Barat. The 2st National Conference on Education, Social Science, and Humaniora Proceeding. 2 (1). 13-20 https://journalcenter.litpam.com/index.php/essh/article/view/343

Mashur, Agustin D.L.A., Ningtyas I.S.N., Multazam A., \& Ningsih M. 2020b. Gelar Teknologi Pengolahan Kotoran Sapi dan Limbah Rumah Tangga Menjadi Eksmecat untuk Meningkatkan Pendapatan Masyarakat. Sasambo: Jurnal Abdimas (Journal of Community Service). 2(3), 86-94 DOI:10.36312/sasambo.v2i3.279https://journal-center.litpam. com/index.php/Sasambo_Abdimas/article/view/279

Mashur, Suhubdy Yasin, Kholik, Dina Oktaviana, Kunti Tirtasari dan Siti Nurus. 2020c. Penerapan manajemen kesehatan kandang Kolektif sapi potong pada peternakan rakyat di Pulau Lombok Pprovinsi Nusa Tenggara Barat. Prosiding Webinar Nasional Sapi Kerbau IV Fakultas Peternkan - Universitas Andalas. ISBN: 978-623-7763-73-4 http:/ / repo.unand.ac.id/36634/1/PRSIDING\%20SAPI\%20KERBAU\%2 OIV.pdf 
Pemerintahan Desa Taman Ayu. 2015. Profil Desa Taman Ayu Kecamatan Gerung Kabupaten Lombok Barat Provinsi Nusa Tenggara Barat. Buku Profil Desa. http://ppid.lombokbaratkab.go.id , fileppid

Roessali, W., B.T. Eddy, dan A. Murthado. 2005. Upaya Pengembangan Usaha Sapi Potong Mmelalui Entinitas Agribisnis "Corporate Farming" di Kabupaten Grobogan. Jurnal Sosial Ekonomi Peternakan 1(1): 25-30.https:// sinta.ristekbrin.go.id/authors / detail?page $=1 \& i d=$ 5990045\&view=documentsgs

Suprapto, A. 2009. FMA sebagai salah satu model pemberdayaan masyarakat tani. Badan Pengembangan SDM Pertanian Kementerian Pertanian RI. Bahan Seminar. Bandung 3 september 2009. https://www.litbang.pertanian.go.id/buku/menuju-pertanianmodern/6.pdf

Warsana. 2020. Paradigma Baru Pemberdayaan Petani Mendukung Pertanian Maju, Mandiri dan Modern. Perspektif Pembangunan Pertanian Jawa Tengah. Penerbit PT. Agro Indo Mandiri. ISBN:978-62393937-2-4 